\title{
Kenakalan Remaja dan Psikososial
}

\author{
Sigit Tri Utomo dan Luluk Ifadah \\ Sekolah Tingi Agama Islam Nahdlatul Ulama Temanggung \\ Email : sigittriutomosukses@gmail.com \\ bundaqotrunnada@gmail.com
}

\begin{abstract}
Adolescents are identical to mental development in both physical, social and spiritual dimensions. Adolescents are also indicated as a time of self discovery seeking to find identity through adaptation to the environment in which the learning environment, playground environment, and community environment interact. Some teenagers who are inappropriate in interacting with a good environment will have a negative impact on their mental development. They do anarchic, brutal, even trapped in immoral, drugs and go to jail. Here the author describes the importance of handling in the spiritual mental development of adolescents so that they do not fall prey to the westernerization pattern.
\end{abstract}

Key words: Adolescents, Juvenile Delinquency, Psychosocial, Self Discovery Seeking

\section{PENDAHULUAN}

Sebagai remaja dengan berbagai perubahan ingin menjadi individu yang relatif lebih mandiri, lebih mendapatkan perhatian dan peranan dari lingkungan keluarga maupun lingkungan yang lebih luas. Mereka bertindak sesuai dengan keinginannya sendiri demi mendapatkan pengakuan peran dan fungsinya, sehingga dalam mengaktualisasikan dalam bentuk-bentuk yangbertentangan, dengan norma dan hukum yang berlaku di dalam masyarakat.

Sesungguhnya masa remaja itu tidak dapat dipastikan secara tegas dimulai dan kapan berakhir, tergantung kepada berbagai faktor. Misalnya faktor perorangan (ada yang cepat dan ada yang lambat). Namun secara mudah dan hampir sama pada tiap anak yaitu kira-kira umur 13 tahun (misalnya mimpi basah pada anak laki-laki dan haid yang pertama (manarche) pada anak perempuan). Ada pula yang berpendapat remaja adalah masa dalam perkembangan manusia, ketika anak berubah dari makhluk a-seksual menjadi makhluk seksual, yaitu ketika anak mulai dari ketertarikan 
pada teman yangberjenis kelamin sama menjadi berubah, yaitu tertarik pada lain (Irwanto, 1989:45).

\section{PERMASALAHAN}

Remaja dalam ilmu psikologis juga diperkenalkan dengan istilah lain, seperti puberteit, adolescence, dan youth. Dalam bahasa Indonesia sering pula dikaitkan pubertas atau remaja. Remaja merupakan suatu fase perkembangan antara masa kanak-kanak dan masa dewasa, berlangsung antara usia 12 sampai 21 tahun. Masa remaja terdiri dari masa remaja awal usia 12-15 tahun, masa remaja pertengahan usia 15-18 tahun, dan masa remaja akhir usia 18-21 tahun. Masa remaja disebut juga sebagai periode perubahan, tingkat perubahan dalam sikap, dan perilaku selama masa remaja sejajar dengan perubahan fisik (Hurlock, 2004: 116). Masa remaja sebagai masa peralihan dari masa anak ke masa dewasa, meliputi semua perkembangan yang dialami sebagai persiapan memasuki masa dewasa. Semua aspek perkembangan dalam masa remaja secara global berlangsung antara umur 12-21 tahun, dengan pembagian usia 12-15 tahun adalah masa remaja awal, 15-18 tahun adalah masa remaja pertengahan, 18- 21 tahun adalah masa remaja akhir (Gunarsa, 2001: 36).

Pertama, Masa Remaja Awal atau usia 12-15 tahun masa ini adalah masa peralihan dari masa sekolah menuju masa pubertas, dimana seseorang anak yang telah besar ini ingin berlaku seperti orang dewasa tetapidirinya belum siap, termasuk kelompok dewasa.

Pra pubertas adalah saat terjadinya kematangan seksual yang sesungguhnya, bersamaan dengan terjadinya perkembangan fisiologis yang berhubungan dengan kematangan kelenjar endoktrin. Kelenjar endoktrin adalah kelenjar yang bermuara langsung di dalam saluran darah, dengan melalui pertukaran zat yang ada diantara jaringan kelenjar dengan pembuluh rambut di dalam kelenjar tadi, zat yang dikeluarkan berupa hormon, selanjutnya hormon ini akan memberikan stimulasi pada tubuh anak sedemikian rupa. Sehingga anak merasakan rangsangan tertentu, rangsangan ini menyebabkan perasaan tidak tenang pada diri anak, suatu rasa yang 
belum pernah dialami sebelumnya pada akhir dunia anak-anak yang cukup menggembirakan

Peristiwa kematangan tersebut terjadi pada wanita 1,5 sampai 2 tahun lebih awal dari laki-laki. Terjadinya kematangan jasmani bagi wanita biasanya ditandai dengan adanya menstruasi pertama sedang pada pria ditandai dengan keluarnya sperma yang pertama, biasanya lewat mimpi merasakan kepuasaan seksual. Kematangan atas jenis kelamin tersbut banyak tergantung dengan iklim, lingkungan budaya setempat, bangsa dan lainnya sehingga peristiwa ini tiap bangsa sering kali terjadi perbedaan waktunya. Bagi remaja awal adanya kematangan jasmani itu digunakan dan dianggap sebagai tanda-tanda primer akan datanganya masa remaja.

Adapun menurut Desnita (2006:109) tanda-tandanya 12-15 tahun sebagai masa remaja awal adalah:

1. Selaput suara semakin besar, tumbuh suburnya rambut, janggut, kumis (laki-laki) dan Kelenjar pada dada mulai menjadi berisi (wanita)

2. Badan mulai membentuk segitiga (laki-laki) dan Pinggul semakin besar dan melebar (wanita)

3. Urat jadi kuat dan muka bertambah persegi (laki-laki). Suara menjadi bulat, merdu, tinggi dan muka menjadi bulat dan berisi (wanita)

Yang kedua, masa pubertas (15-18 tahun), Pada masa ini seorang anak tidak hanya bersifat reaktif, tetapi juga sudah mulai aktif mencapai kegiatan dalam rangka menemukan dirinya, serta mencari pedoman hidup, untuk bekal kehidupannya mendatang.

Tanda masa pubertas menurut E. Spranger dalam Ahmadi dan Sholeh (dalam Desnita, 2006: 112) menyebutkan ada tiga jenis aktivitas yaitu:
a. Penemuan jati diri
b. Pertumbuhan pedoman kehidupan
c. Memasukkan diri pada kegiatan kemasyarakatan 
Perbedaan sikap hidup laki-laki dan perempuan dibedakan sebagai berikut:

a. Aktif memberi (laki-laki) dan Pasif dan menerima (wanita)

b. Cenderung untuk memberikan perlindungan (laki-laki) dan Cenderung untuk menerima perlindungan (wanita)

c. Minatnya tertuju pada hal yang bersifat intelektual (laki-laki) dan abstrak Minat tertuju pada yang bersifat emosional dan konkrit (wanita)

d. Berusaha memutuskan sendiri dan ikut berusaha (laki-laki, sedangkan Berusaha mengikut dan menyenangkan orang tua (wanita)

e. Sifat objektif (laki-laki) dan Sikap subjektif (wanita)s

Yang ketiga Masa Adoleson / Dewasa (18 - 21 tahun) Pada masa ini seseorang sudah mengetahui kondisi dirinya, ia sudah mulai membuat rencana kehidupan serta sudah mulai memilih dan menentukan jalan hidup yang hendak ditemuinya. Sifat masa adoleson dapat diungkapkan antara lain

a. Menunjukkan timbulnya sikap positif dalam menentukan sistem tata nilai yang ada

b. Menunjukkan adanya ketenangan dan keseimbangan di dalam kehidupan

c. Mulai menyadari bahwa sikap aktif, mengkritik waktu ia pubertas itu mudah tetapi melaksanakannya sulit

d. Ia mulai memiliki rencana hidup yang jelas dan mapan

e. la mulai senang menghargai sesuatu yang bersifat historis dan tradisi, agama, kultur, etis, dan estetis serta ekonomis

f. Dalam menentukan pendamping hidup, sudah tidak lagi berdasarkan nafsu seks belaka, tetapi sudah atas dasar pertimbangan yang matang dari berbagai aspek

g. Mulai mengambil/menentukan sikap hidup berdasarkan sistem nilai yang diyakininya

h. Pandangan dan perasaan yang semakin menyatu atau melebar antara erotic dan seksualitas yang masa sebelumnya terpisah| 


\section{METODE}

Penelitian ini merupakan penelitian studi pustaka. Dalam tahapan ini, peneliti berusaha menyeleksi data-data (buku) yang ada relevansinya dengan kenakalan remaja dan psikososial. Dengan analisis data hermeneutika sebagai proses mengubah sesuatu dari situasi ketidaktahuan menjadi mengerti, secara harfiah dapat diartikan sebagai penafsiran atau interpretasi. Langkah metode ini dimaksud untuk menangkap arti, nilai dan maksud kenakalan remaja dan psikososial. Kemudian penulis juga mengunakan analisis sintesis yaitu dengan penanganan terhadap objek ilmiah tertentu dengan jalan menggabungkan pengertian yang satu dengan pengertian lain, yang pada akhirnya dapat diperoleh pengetahuan yang sifatnya baru yaitu urgensi perpustakaan sebagai upaya pengurangan perilaku penyimpangan siswa di sekolah. Penulis juga menggunakan content analysis maksudnya ialah "penelitian yang dilakukan terhadap informasi yang didokumentasikan dalam rekaman, baik gambar, suara, tulisan dan lain-lain. Dengan metode ini akan dilakukan analisis data dan pengolahan secara ilmiah tentang isi tulisan kenakalan remaja dan psikososial.

\section{PEMBAHASAN}

\section{Psikososial Kenakalan Remaja dan Perilaku Menyimpang}

Secara etimologis kenakalan remaja berasal dari bahasa latin darikata juvenile delinquency, dapat dijabarkan Juvenile yang berarti anak, sedangkan delinquency berarti kejahatan. Dengan demikian pengertian secara etimologis adalah kejahatan anak. Dalam perumusan arti kenakalan remaja (Juvenile delinquency) oleh karena itu para psikolog mengalami pergeseran mengenai kualitas subjek dari kenakalan anak menjadi kenakalan remaja dalam pengertian yang luas tentang kenakalan remaja ialah perbuatan kejahatan atau pelanggaran yang dilakukan oleh karena itu anak remaja yang bersifat melawan hukum, antisosial, anti susila dan menyalahi norma-norma agama. (Sudarsono, 2004:11).

Kehidupan sebagai remaja merupakan salah satu periode dalam rentang kehidupan manusia. Banyak terjadi perubahan baik dari segi fisik maupun psikis. Menurut Elida Prayitno (2006:49) perubahan yang terjadi pada awal masa remaja 
meliputi perubahan sistem pencernaan, perubahan sistem syaraf, perubahan sistem pernafasan, dan perubahan organ seks. Dalam masa perubahan organ seksual, baik primer maupun sekunder itu, sebagian remaja mengalami kesulitan seperti merasa sakit saat haid, perasaan sedih dan kecewa karena tidak percaya diri dengan perubahan tubuh. Kurangnya pendidikan seksual terhadap remaja akan menimbulkan penyimpangan tingkah laku seksual pada remaja.

Sunarwiyati S, dalam (Prayitno, 2006 ) membagi kenakalan remaja kedalam tiga tingkatan:

1. Kenakalan biasa, seperti suka berkelahi, suka keluyuran, membolos sekolah, pergi dari rumah tanpa pamit

2. Kenakalan yang menjurus pada pelanggaran dan kejahatan seperti mengendarai mobil tanpa SIM, mengambil barang orang tua tanpa izin

3. Kenakalan khusus seperti penyalahgunaan narkotika, hubungan seks diluar nikah, pergaulan

4. bebas, pemerkosaan dll. Kategori di atas yang dijadikan ukuran kenakalan remaja dalam penelitian.

Adapun penulis menambahkan beberapa kenakalan remaja meliputiperjudian. Perjudian merupakan salah satu bentuk penyakit masyarakat,perjudian bisa berupa permainan anak-anak kecil yang di dalamnyaada unsur pertaruhan, permainan itu bisa berupa permainan dari kartu,dadu dan segala bentuk sport dan games.

\section{Faktor Penyebab Kenakalan Remaja}

Menurut Kartono (2008:93) menjelaskan beberapa teori masalah yang menyebabkan terjadinya kenakalan remaja yaitu:

1. Teori Biologis

Tingkah laku sosiopatik atau dilinkuen pada anak-anak dan remaja dapat muncul karena faktor-faktor fisiologis dan struktur jasmaniah seseorang, juga dapat cacat jasmaniah yang dibawa sejak lahir. Kejadian ini berlangsung;

a. Melalui gen atau plasma pembawa sifat dalam keturunan, atau melalui kombinasi gen; dapat juga disebabkan oleh tidak adanya gen tertentu, yang 
bisa menyebabkan munculnya penyimpangan tingkah laku, daan anak-anak menjadi dilinkuen secara potensial.

b. Melalui pewarisan tipe-tipe kecenderungan yang luar biasa (abnormal), sehingga membuahkan tingkah-laku dilinkuen.

c. Melalui pewarisan kelemahan constitutional jasmaniah tertentu yang menimbulkan tingkah laku dilinkuen atau sosiopatik. Misalnya cacat jasmaniah bawaan brachydactylisme (berjari-jari pendek) dan diabetes insipidius (sejenis penyakit gula) itu erat berkolerasi dengan sifat kriminal serta penyakit mental.

2. Teori psikogenis

Teori ini menekankan sebab-sebab tingkah laku dilinkuen anak-anak dari aspek psikologis atau isi kejiwaannya. Antara lain faktor intelegensi, ciri kepribadian, motivasi, sikap-siikap yang salah, fantasi, rasionalisasi, internalisasi diri yang keliru, konflik batin, emosi yang controversial, kecendrungan psikopotologis,dan lain-lain. Argumen sentral teori ini ialah sebagai berikut; dilinkuen merupakan "bentuk penyelesaian" atau kompensasi dari masalah psikologis dan konflik batin dalam melengkapi stimuli eksternal/sosial dan polapola hidup keluarga yang patologis. Kurang lebih 90\% dari jumlah anak-anak dilinkuen berasal dari keluarga berantakan (broken home).Kondisi keluarga yang tidak behagia dan tidak beruntung, jelas membuahkan masalah psikologis personal dan adjustment (penyesuaian diri) yang terganggu pada diri anak-anak; sehingga mereka mencari kompensasi diluar lingkungan keluarga guna memecahkan kesulitan batinnya dalam bentuk prilaku dilinkuen.Ringkasannya, dilinkuensi atau kejahatan anak-anak merupakan reaksi terhadap masalah psikis anak remaja itu sendiri.

\section{Teori Sosiogenesis}

Teori ini berpendapat bahwa penyebab tingkah laku delinquent pada anakanak remaja murni sosiologis atau sosial-psikologis sifatnya.Misalnya disebabkan oleh struktur sosial yang deviatif, tekanan kelompok. Peranan sosial, status sosial atau internalisasi yang keliru. Maka faktor-faktor kultural dan sosial itu sangat mempengaruhi. Dalam penentuan konsep diri yang penting adalah simbolisasi diri 
atau "penanaman diri”, disebut pula sebagai pendefinisian diri atau peranan diri. Dalam subjek ini mereka mempersamakan diri mereka dengan tokoh-tokoh penjahat. Sehingga ini menjadi konsep hidupnya dan menjadi konsep diri yang disesuaikan dengan situasi sesaat.

Proses simbolisasi diri umumnya dilakukaan secara tidak sadar dan berangsurangsur sehingga menjadi sebuah bentuk kejahatan delinkuin pada diri anak-anak dan remaja. Sebab-sebab kenakalan remaja itu tidaj terltak dilingkungan keluarga atau tetangga saja akan tetapi terutama sekali disebabkan oleh kontaks kulturasinya. Maka karier kejahatan anak itu jelas dipupuk dari lingkngan yang buruk dan jahat ditambah dengan kondisi sekolah yang kurang menarik bagi anak, konsep untuk bisa memahami sebab dari kenakalan remaja itu ialah perhaulan dengan anak-anak muda lainya yang sudah delinquent. Anak menjadi delinquent dikarenakan partisipasinya ditengah-tengan lingkunag sosial yang ide dan teknik delinquent tertentu menjadi saran yang special untuk mengatasi keulitan hidupnya. Karena itu semkain lama anak bergaul semakin tinggi tingkat intensif relasasinya dengan anak-anak jahat lain akan semakin lama pula proses berlangsungnya asosiasi diferensial tersebut.dan semakin besar kemungkinan anak-anak remaja tadi menjadi kriminal.

4. Teori Subkultar Delinkuensi

Tipe teori yang terdahulu (biologis, psikogenesis, dan sosiogensis) sangat popular sampai tahun 50-an. Sejak itu banyak terdapat perhatian pada aktivitas-aktivisas kenakalan remaja yang terorganisir dengan subkultarnya, adapun penyebabnya adalah :

a. Bertambahnya dengan cepat jumlah kejahatan, dan meningkatkanya kualitas kekerasan serta kekejaman yang dilakukan oleh anak-anak remaja yang mempunyai subkultur delinkuin.

b. Meningkatkan jumlah kriminalitas menyebabkan meningkatnya jumlah kerugian dan kerusakan secara universal, terutama untuk negara-negara industri yang lebih maju dikarenakan meningkatnya jumlah kenakalan pada anak-anak remaja. Kultur atau "kebudayaan” dalam hal ini satu kumpulan nilai 
dan norma yang menuntun bentuk tingkah laku responsif sendiri yang khas pada anggota-anggota kelompok yang sudah terbentuk. Sedangkan istilah "sub" tadi mengidentifikasikan budaya yang bisa muncul ditengah system yang lebih inklunsif sifatnya.

Berdasarkan subkultur ini sifat-sifat suatu struktur sosial dengan pola budaya (subkultur) yang khas dari lingkungan familial, tetangga dan masyarakat yang didiamioleh para remaja delinquent tersebut. Sifat-sifat masyarakat tersebut antara lain adalah :

1) Punya populasi yang padat,

2) Status sosial ekonominya rendah,

3) Kondisi fisik dan perkampungan yang sangat buruk,

4) Banyak disorganisasi famili dan social bertingkat tinggi.

Karena itu sumber utama kemunculan kejahatan remaja ialah subkultar-subkultardelinquen dalam konteks yang lebih luas dalam kehidupan masyarakat. Kemudian subkultur itu merupakan reaksi terhadap permasalahan sosial stratifikasi penduduk dengan status sosial rendah yang ada di satu daerah yang menilai secara berlebihan status sosial tinggi dan harta kekayaan.

\section{Sebab Kenakalan Remaja}

Menurut Kartono (2008:93) yang menjadi sebab kenakalan remaja adalah sebagai berikut:

\section{Faktor dalam diri sendiri}

a. Predisposing Faktor

Predisposing Faktor adalah faktor yang memberi kecenderungan tertentu terhadap perilaku remaja. Faktor tersebut dibawa sejak lahir, atau oleh kejadian-kejadian ketika kelahiran bayi yang disebut dengan birth injury, yaitu luka di kepala bayi ketika bayi ditarik dari perut ibu. Predisposing faktor ini antara lain berupa kelainan kejiwaan.Kecenderungan kenakalan remaja adalah dari faktor bawaan bersumber dari kelainan otak.Menurut 
pemahaman Freudian bahwa kepribadian jahat (delingquent) bersumber dari id (bagian kepribadian yang bersumnber dari hawa nafs

b. Lemahnya pertahanan diri

Adalah faktor dalam diri untuk mengontrol dan mempertahankan diri terhadappengaruh negatif dari lingkungan. Sebagai upaya untuk menolak terhadappengaruh negatif Trower dalam Willis (2010:88) adalah denganmengembangkan ketrampilan sosial meliputi:

1) Mengembangkan persepsi terhadap bahaya yang ada dilingkungan

2) Menafsirkan persepsi tersebut

3) Tindakan yang terencana untuk melawan bahaya

c. Kurangnya kemampuan penyesuaian diri

Ketidakmampuan penyesuaian diri terhadaplingkungan sosial denganmempunyai daya pilih teman bergaul yang membantu pembentukan perilakupositif.

d. Kurangnya dasar - dasar keimanan di dalam remaja

Sekolah dan orang tua harus bekerja sama dalam memberikan pendidikanagama secara baik, mantap dan sesuai dengan kondisi remaja saat ini.

\section{Faktor lingkungan Keluarga}

a. Keluarga

Keluarga merupakan sumber utama atau lingkungan pertama penyebabkenakalan remaja ini disebabkan karena anak itu hidup dan berkembangpermulaan sekali dari pergaulan keluarga yaitu hubungan antara orang tuadengan anak, ayah dengan ibu dan hubungan anak dengan anggota keluargalain yang tinggal bersama-sama. Keluarga yang besar jumlah anggotakeluarganya pengawasanya agak sukar dilaksanakan dengan baik, demikianjuga dalam menanamkan disiplin terhadap masing-masing anak. Berbeda dengakeluarga kecil, pengawasan dan displin dapat dengan mudah dilaksanakan. 
b. Ekonomi

Masa remaja penuh dengan keinginan, keindahan dan cita-cita.Para remajamenginginkan beragam mode pakaian, kendaran, hiburan dansebagainya.Remaja menuntut agar keluarga dapat memenuhi setiapkeinginannya. Bila keluarga tidak bisa memenuhi maka akan timbul perasanrendah diri pada remaja, akibatnya akan timbul berbagai masalah sosial yangdisebabkan karena gagal dalam memenuhi kebutuhannya

c. Disharmoni keluarga

Sebuah keluarga dikatakan harmonis jika struktur keluarga itu utuh daninteraksi diantara anggota keluarga berjalan dengan baik, artinya hubunganpsikologis antara mereka cukup memuaskan dirasakan dirasakan oleh setiapanggota keluarganya. Kenakalan remaja bisa disebabkan karena pertengkaranorang tua.

\section{Faktor lingkungan masyarakat}

a. Kurangnya pelaksanaan ajaran agama secara konsekuen

Di dalam ajaran agama terdapat banyak hal yang dapat membantu pembinaananak pada umumnya, anak dan remaja pada khususnya. Masyarakat yangkurang beragama akan merupakan sumber dari berbagai kejahatan sepertikekerasan, perampokan, judi, dan sebagainya. Keadaaan tersebut akancenderung akan diikuti oleh remaja yang masih dalam tahap perkembangan.

b. Masyarakat yang kurang memperoleh pendidikan

Masyarakat yang kurang berpendidikan cenderung akan membiarkan perilakunegatif remaja dan menganggap sebagai persoalan yang dapat ditolerir.

c. Kurang pengawasan terhadap remaja.

Sebagian remaja beranggapan bahwa orang tua dan guru terlalu ketat sehinggatidak memberi kebebasan baginya. Pengawasan terhadap anak seharusnyadimulai sejak dini, jika dimulai pada masa remaja dapat menimbulkan konflik 
d. Pengaruh norma baru dari luar

Kebanyakan remaja menilai bahwa setiap norma yang datang dari luar, itulahyang benar. Sehingga mereka cenderung berperilaku dengan norma baru.Norma yang dianut sebelumnya bisa bertentangan dengan norma yang barudidapatkan sehingga hal ini memicu terjadinya konflik pada remaja.

\section{Faktor lingkungan sekolah}

a. Faktor guru

Dedikasi guru merupakan pokok terpenting dalam tugas mengajar.Guru yang berdedikasi biasanya ikhlas dalam mengajar, tidak mudah mengeluh dan mengalah.Berbeda dengan guru yang tidak memiliki dedikasi yang hanyasebagai melaksanakan kewajiban mengajar sebatas karena gaji bukan karenaada keinginan untuk mengarahkan siswa pada persoalan yang baik.Akibatnyasiswa sering kacau, pulang terlebih dahulu karena gurunya tidak ada.

b. Ekonomi guru

Jika ekonomi guru kurang baik, tentu akan berusaha untuk mencukupinyadengan mencari diluar sekolah, sehingga guru banyak menghabiskan waktunyadi tepat lain. Hal ini akan berdampak pada pembelajaran disekolah.

C. Mutu guru

Mutu guru berkaitan dengan kemampuan dalam mendidik siswa. Guru yangbermutu cenderung akan bisa mendidik siswanya pada persoalan yang positif

d. Fasilitas pendidikan

Fasilitas pendidikan berkaitan erat dengan penyaluran bakat dan kemampuan siswa. Bakat dan kemampuan yang tidak tersalurkan memungkinkan merekaakan memenuhinya diluar sekolah bahkan yang bersifat negatif. 
e. Norma-norma pendidikan dan kekompakan guru

Konsistensi guru atas aturan yang telah ditetepkan menjadi penting dandiperhatikan oleh siswa, jika guru konsisten memungkinkan siswa juga akankonsisten dan begitu pula sebalinya. Perilaku guru tersebut akan diikuti olehsiswa dalam kehidupannya.

f. Kekurangan guru

Kelengkapan guru disekolah sangat menunjang kegiatan pembelajaran.Guruyang lengkap memungkinkan tidak ada kelas yang kosong sehingga siswadisibukkan dengan belajar. Sebaliknya jika guru kurang maka akan banyak kelasyang kosong sehingga siswa tidak bisa diawasi oleh guru.

\section{Penyimpangan Remaja pada Aspek Seksualitas}

Menurut Santrock dalam (Kartono, 2008:196), menjelaskan masalah-masalah yang dihadapiremaja dalam proses perkembangan:

a. Pendekatan Biopsikososial (biopsychosocial Approach)

Menekankan pengaruh interaktif dari faktor-faktor biologis, psikologis dansosial terhadap berkembangnya masalah-masalah remaja dan orang-orang yangberasal ari berbagai usia lainnya.

1) Faktor-faktor Biologis

Menurut pendekatan biologis, masalah-maslaah remaja disebabkan olehkegagalan dari fungsi-fungsi tubuhnya.Para ilmuwan yang menganut pendekatanbiologis biasanya berfokus pada faktor otak dan faktor genetic sebagai penyebabtimbulnya masalah-masalah remaja.Pendekatan biologis sering menggunakanterapi obat untuk menangani masalah yang timbul.

2) Faktor-faktor Psikologis

Beberapa faktor psikologis yang dianggap sebagai penyebab timbulnya masalahadalah gangguan berfikir, gejolak emosional,proses belajar yang meliru, danrelasi yang bermasalah. Ingatlah bahwa pada teoritispsikoanalisis mengatribusikan timbulnya masalah-masalah pada pengalamanstress dengan orang tua di masa awal kehidupan. Sementara 
para teorisbehavioral dan kognitif sosial memandang masalah-masalah remaja sebagaiakibat dari pengalaman sosial bersama orang lain. Secara khusus pengaruhkeluarga dan kawan-kawan sebaya di anggap memiliki kontribusi yang pentingterhadap timbulnya masalah-masalah remaja

3) Faktor-faktor Sosial

Masalah-masalah psikologis yang berkembang pada remaja juga muncul di sebagian besar budaya. Meskipun demikian, frekuensi dan intensitas masalah-masalahtersebut bervariasi antara budaya yang satu dengan yang budayayanglain, di mana variasi ini berkaitan dengan aspekaspek budaya seperti aspeksosial, ekonomi, teknologi, dan agama.Faktorfaktor sosial yang mempengaruhiperkembangan masalah-masalah remaja dapat meliputi status sosial ekonomi dankualitas lingkungan tempat tinggal.

4) Pendekatan Psikopatologi Perkembangan

Bidang psikopatologi perkembangan (developmental psychopathology) berfokuspada upaya mendiskipsikan dan mengeskplorasi jalur perkembanganmasalah.Masalah-masalah remaja dapat dikategorikan dalam internalisasi daneksternalisasi :

a) Internalisasi masalah (internalizing problems) timbul ketika individumengarahkan masalah-masalah yang dialami ke dalam dirinya.

b) Eksternalisasi masalah (externalizing problems) timbul ketika individu mengarahkan masalah-masalah yang di alami ke luar dirinya.Para ilmuan juga telah menemukan kaitan antara pola-pola dari masalah yangtimbul di masa kanak-kanak dengan dampaknya di masa dewasa. Dalam sebuah studiditemukan bahwa laki-laki yang memiliki pola internalisasi (seperti kecemasan dandepresi) di masa sekolah dasar cenderung akan mengalami bentuk masalah-masalahyang serupa diusia 21 tahun, namun mereka tidak memperlihatkan resiko untukmelakukan eksternalisasi masalah di masa dewasa muda. Demikian pula timbulnyapola eksternalisasi (seperti perilaku agresi dan 
antisosial) di masa kanak-kanak dapatmeningkatkan resiko timbulnya masalah antisosial pada masa 21 tahun. Untukperempuan dan pola eksternalisasi dapat memprediksikan masalah internalisasi diusia 21 tahun.

Menurut Willis dalam (Fatchurohman, 2001) menjelaskan masalah penyimpangan seks pada remajasebagai berikut:

1. Onani

Kelainan perilaku seks biasanya dilakukan oleh laki laki yang merasa inginmemenuhi kebutuhan seksnya, dilakukan dengan cara mengeluarkan air mani olehtangan. Biasanya dilakukannya dengan sembunyi-sembunyi atau pada waktu tidurOnani dapat mengakibatkan lemah syahwat dan bahkan melemahkan spermasehingga tidak sanggup membuahi sel telur wanita. Efek samping lain dari onani iniadalah efek psikologisnya di mana si pelaku sering merasa berdosa sehinggamenimbulkan psikoneurosa atau gangguan kejiwaan.

2. Homoseksual

Kelainan perilaku seks yang dilakukan oleh 2 individu yang berjenis kelamin sama dinamakan homoseksual. Laki laki dengan laki laki dinamakan (male sexuality)atau lebih umum disebut dengan homoseksual saja.Wanita dengan wanita disebutlesbians. Ada 3 macam homoseksual itu :

a. Aktif, bertindak sebagai pria dan tidak bergantung pada temanseksnya

b. Pasif, yaitu bertindak sebagai wanita

c. Campuran, yaitu kadang kadang sebagai pria dan kadang kadangsebagai wanita.

Sebab sebab terjadinya perbuatan homoseksual itu ;

a. Faktor hereditas (dibawa sejak lahir). Ini jarang terjadi.

b. Adanya ketidakseimbangan hormon seks (sex hormonal imbalance)

3. Pengaruh lingkungan, yang meliputi:

a. Terpisah dari lawan jenis dalam waktu yang lama misalnya dipenjara dan di asrama 
b. Pengalaman hubungan seks dengan sesame jenis pada waktu kecil(masa kanak kanak), dengan istilah sodomi.

c. Kesalahan perlakuan yakni anak laki laki yang hidup di rumahtangga di mana semua saudaranya perempuan. Jika anak inidiperlakukan sebagai anak perempuan setiap harinya misalnyadibedaki, diberi pakaian wanita, dan lain lain. Maka akan tumbuhsifat sifat kewanitaan pada dirinya (merasa diri sebagai jenis kelaminwanita)

4. Pelacuran

Pengertian pelacuran ialah perilaku seks bebas yang dilakukan secara tidaksah menurut hukum dan agama, yang terjadi di dalam masyarakat.Biasanya wanitayang melakukan disebut wanita $\mathrm{p}$ (singkatan dari pelacur), dan laki lakinyadinamakan laki laki hidung belang. Wanita $\mathrm{P}$ itu biasnya berkeliaran malam malam ditaman taman, di pinggir jalan dan tempat tempat tertentulainnya untuk menanti laki-laki yang akan menjemputnya. Tingkat pelacuran seperti ini dinamakan pelacurantingkat rendah. Disamping itu ada lagi pelacur tingkat tinggi, yaitu mempunyai rumahsendiri, atau di hotel-hotel kelas wahid.

Usaha mengatasi pelacuran dengan cara menampungnya kegiatan mereka ditempat-tempat yang disediakan khusus, belum pasti akan dapat menyelesaikanmasalahnya bahkan bukan tidak mungkin dengan cara lokalisasi itu pelacuran akanlebih pesat berkembangnya, yang terpenting dalam usaha menanggulangi pelacuranitu ialah dengan cara mengetahui sebab-sebab terjadinya, meningkatkan sanksi/hukum bagi si pelakunya, dan menyalurkan wanita $P$ itu pada kegiatan yangbermanfaat bagi dirinya dan masyarakatnya.

Pada umumnya sebab-sebab terjadinya pelacuran ialah:

a. Rendahnya taraf ekonomi rakyat.

b. Banyaknya pengaruh barang-barang mewah mendorong orang untukmemilikinya

c. Kehidupan rumah tangga yang tidak harmonis baik dibidang pergaulan,ekonomi, atau hubungan seks yang tidak memuaskan. 
d. Meningkatkan film-film dan video porno, gambar-gambar cabul dimasyarakat dimana penggemarnya sebagian besar adalah remaja sekolah.Dengan mengetahui sebab-sebab terjadinya akan lebih mudah bagi kita untukmengatasinya daripada hanya dengan cara yang berdasarkan selera orang ataukelompok tertentu yang sudah terpengaruh oleh cara-cara negara barat yang tidakpancasialis.

5. Pornografi Dan Pornoaksi

Hal hal yang berusaha untuk merangsang dorongan seks untuk tulisan ataugambar.Pengaruhnya cepat luas terutama dikalangan remaja yang sedang berada dimasa pubertas. Hal ini bisa berakibat menimbulkan krisis moral di kalangan remajaitu, terutama apabila dasar dasar agama kurang sekali dilatihkan sejak kecil. Usahapornografi juga bisa melemahkan potensi bangsa, akibatnya dapat merusak sendisendifalsafah pancasila.

Pornografi dapat mengakibatkan perilaku negatif seperti berikut ini:

a. Mendorong remaja untuk meniru melakukan tindakan seksual

Kemampuan remaja menyaring informasi masih rendah. Para ahli di bidang kejahatan seksual terhadap remaja juga menyatakan bahwa aktivitasseksual pada remaja yang belum dewasa selalu dipicu oleh 2 (dua)kemungkinan yaitu pengalaman atau melihat. pornografi atau aktivitas pornobaik dari internet, HP, VCD, komik atau media lainnya. Maka mereka akan terdorong untuk meniru melakukan tindakan seksual terhadap anak lainataupun siapapun obyek yang bisa mereka jangkau.

b. Membentuk sikap, nilai dan perilaku yang negatif

Donald (2004),pornografi dapat mengakibatkan perilaku negatifseperti berikut ini:

1) Mendorong remaja untuk meniru melakukan tindakan seksual

Kemampuan remaja menyaring informasi masih rendah. Para ahli dibidang kejahatan seksual terhadap remaja juga menyatakan bahwa aktifitasseksual pada remaja yang belum dewasa selalu dipicu oleh 2 (dua) kemungkinan yaitu pengalaman atau melihat. pornografi atau aktivitas 
pornobaik dari internet, HP, VCD, komik atau media lainnya. Maka mereka akanterdorong untuk meniru melakukan tindakan seksual terhadap anak lainataupun siapapun obyek yang bisa mereka jangkau.

2) Membentuk sikap, nilai dan perilaku yang negatif.

Beragam adegan seksual, dapat terganggu proses pendidikan seksnya. Hal itu dapat diketahui dari cara mereka memandang wanita, kejahatan seksual, hubungan seksual, dan seks pada umumnya. Remaja tersebut akan berkembang menjadi pribadi yang merendahkan wanita secara seksual, memandang seks bebas sebagai perilaku normal dan alami, permisif terhadap perkosaan, bahkan cenderung mengidap berbagai penyimpangan seksual.

3) Menyebabkan sulit konsentrasi belajar hingga terganggu jati dirinya Pada remaja yang memiliki IQ tinggi, pornografi bisa mengakibatkanmereka kesulitan membangkitkan konsentrasinya untuk belajar dan beraktivitas, hari-harinya didominasi oleh kegelisahan dan sedikit sekaliproduktivitasnya. Sedangkan remaja yang ber-IQ rendah, pengaruhnya bisalebih ekstrim lagi, mereka tidak berdaya lagi untuk berkonsentrasi, hari-harinya total dikuasai kegelisahan.

Pornografi yang ditonton remaja merupakan sensasi seksual yang diterima sebelum waktunya, sehingga yang terjadi adalah mengendapnya kesan mendalam di bawah otak sadar yang bisa membuat mereka sulitkonsentrasi, tidak fokus, malas belajar, tidak bergairah melakukan aktivitasyang semestinya, hingga mengalami shock dan disorientasi (kehilanganpandangan) terhadap jati diri mereka sendiri bahwa sebenarnya mereka masihremaja.

4) Tertutup, minder dan tidak percaya diri

Remaja pecandu pornografi yang mendapat dukungan temantemannyasesama penggemar pornografi, akan terdorong menjadi pribadi yang permisif(memandang maklum) terhadap seks bebas dan mereka melakukan praktekseks bebas di luar pantauan orang tua. Sedangkan 
remaja pecandu pornografiyang dikelilingi oleh teman-teman yang terbimbing dan bebas dari pornografi,akan cenderung merasa minder dan tidak percaya diri. Karena kebiasaannyaini, remaja merasa sebagai pribadi yang aneh dan berbeda perilakunya, danseiring bertambahnya pengetahuan keagamaannya ia akan merasa palingberdosa.

c. Perilaku seksual menyimpang pada orang lain

Dari hasil penelitian diperoleh bahwa perilaku menyimpang pada oranglain berada pada kategori "tinggi" dilakukan oleh siswa. Temuan ini didukungoleh pendapat Donald, dkk (2004), dampak pornografi terhadap orang lain sebagai berikut':

1) Tindakan kriminal atau kejahatan, tindakan ini umumnya dilihat bertentangandengan norma hukum, norma sosial, dan norma agama yang berlaku dimasyarakat.

2) Penyimpangan seksual adalah perilaku yang tidak lazim di lakukan. Beberapajenis penyimpangan seksual antara lain, lesbianisme, dan homoseksual,sodomi, sadisme, dan pedophilia.

\section{Upaya Menanggulangi Kenakalan Remaja}

Menu rut Willisdalam (Donald, 2004) menjelaskan bahwa terdapat beberapa hal yangbisa dilakukan untuk mengurangi terjadinya kenakalan pada remaja sebagai berikut:

1. Upaya preventif

Upaya preventif adalah kegiatan yang dilakukan secara sistematis, berencana,dan terarah untuk menjaga agar kenakalan itu tidak terjadi sebagai berikut:

a. Di rumah, meliputi:

1) Menciptakan lingkungan yang agamis

2) Menciptakan lingkungan keluarga yang harmonis

3) Adanya kesamaan antar keluarga norma dalam mendidik anak 
4) Memberikan perhatian yang memadahi terhadap kebutuhan anak

5) Memberikan pengawasan secara wajar terhadap pergaulan anak

b. Di sekolah, meliputi:

1) Guru memahami aspek psikis murid

2) Mengintensifkan pelajaran agama

3) Mengintensifkan bagian bimbingan dan konseling

4) Adanya kesamaan norma yang dipegang oleh guru dalam mendidik murid

5) Melengkapi fasilitas sekolah

6) Perbaikan ekonomi guru

c. Di masyarakat

Masyarakat adalah tempat pendidikan ketiga sesudah rumah dan sekolah. Ketiga haruslah mempunyai keseragaman dalam mengarahkan anak untuktercapainya tujuan pendidikan. Apabila salah satunya pincang maka akanberdampak pada lainnya. Pendidikan dimasyarakat sering diabaikan oleh sebagian orang karena mereka beranggapan bahwa pendidikan cukup disekolah. Masyarakat berperan serta agar tujuan pendidikan dapat tercapai halini dengan memberikan pengawasan atas perilaku anak agar tetap sesuaidengan tujuan pendidikan.

2. Upaya kuratif

Upaya kuratif adalah antisipasi terhadap gejala kenakalan, supaya kenakalantersebut tidak meluas. Upaya kuratif biasanya dilakukan oleh polri dan kejaksaannegeri. Sebab jika terjadi kenakalan remaja sudah dapat berakibat merugikan dirimereka dan masyarakat.Berbagai jenis kenakalan telah dijelaskan dalam bakolak Inpres 6/1971 yaitu :pencurian, penipuan, perkelahian, pengruskan, penganiayaan, perampokanpenyalahgunaan narkotika, pembunuhan, pelanggaran susila dan kejahatan lainnya. 
3. Upaya pembinaan

Upaya pembinaan dimaksudkan untuk:

a. Pembinaan terhadap remaja yang tidak melakukan kenakalan dilaksanakandirumah, sekolah, dan masyarakat. Pembinaan seperti ini telah diungkapkanpada upaya preventif sebelumnya.

b. Pembinaan terhadap remaja yang telah mengalami tingkah laku kenakalanatau yang telah menjalani suatu hukuman karena kenakalannya. Hal tersebutperlu dibina agar mereka dapat tidak mengulangi lagi kenakalannya.

Setelah diketahui penyebab terjadinya kenakalan remaja, maka ada beberapa hal yang bisa dilakukan untuk mengatasi kenakalan remaja adalah :

a. Kegagalan mencapai identitas peran dan lemahnya kontrol diri bisa dicegah atau diatasi denganprinsip keteladanan. Remaja harus bisa mendapatkan sebanyak mungkin figur orang-orangdewasa yang telah melampaui masa remajanya dengan baik juga mereka yang berhasilmemperbaiki diri setelah sebelumnya gagal pada tahap ini.

b. Adanya motivasi dari keluarga, guru, teman sebaya untuk melakukan point pertama.

c. Kemauan orangtua untuk membenahi kondisi keluarga sehingga tercipta keluarga yangharmonis, komunikatif, dan nyaman bagi remaja.

d. Remaja pandai memilih teman dan lingkungan yang baik serta orangtua memberi arahan dengan siapa dan di komunitas mana remaja harus bergaul.

e. Remaja membentuk ketahanan diri agar tidak mudah terpengaruh jika ternyata teman sebayaatau komunitas yang ada tidak sesuai dengan harapan.

f. Pemberian ilmu yang bermakna yang terkandung dalam pengetahuan dengan memanfaatkanfilm-film yang bernuansa moral, media massa ataupun perkembangan teknologi lainnya.

g. Memberikan lingkungan yang baik sejak dini, disertai pemahaman akan perkembangan anakanakkita dengan baik, akan banyak membantu mengurangi kenakalan remaja 
h. Membentuk suasana sekolah yang kondusif, nyaman buat remaja agar dapat berkembang sesuaidengan tahap perkembangan remaja.

\section{PENUTUP}

Kenakalan remaja dan psikosial pada diri remaja seharusnya menjadi perhatian serius seperti orang tua, pendidik, stake holder, praktisi psikologi, praktisi hukum dan pemerintah serta peran masyarakat. Adapun solusi internal bagi seorang remaja dalam mengendalikan kenakalan remaja antara lain, kegagalan mencapai identitas peran dan lemahnya kontrol diri bisa dicegah atau diatasi dengan prinsip keteladanan, adanya motivasi dari keluarga, guru, teman sebaya untuk aktivitas positif, remaja menyalurkan energinya dalam berbagai kegiatan positif, remaja pandai memilih teman dan lingkungan yang baik serta orangtua memberi arahan dengan siapa dan di komunitas mana remaja harus bergaul. Karena remaja menjadi pilar regenerasi bangsa Indonesia.

\section{REFERENSI}

Elizabeth, Hurlock. 2004. Psikologi Perkembangan, Erlangga: Jakarta.

Gunarsa, Singgih. 2001. Psikologi Perkembangan, Gunung Mulia: Jakarta.

Irwnto, dkk, 1989. Psikologi Umum, Jakarta: PT Gramedia.

Kartono, Kartini. 2008. Psikologi Remaja, Bandung : PT.Rosda Karya.

Prayitno, Elida. 2006. Psikologi Perkembangan Remaja. Padang: Universitas Negeri Padang.

Sarwono, Sarlito W. 2008 Psikologi Remaja. Jakarta : Raja Grafindo Persada.

Sudarsono, 1990. Kenakalan Remaja, Jakarta : Rineka Cipta.

Donald, dkk. 2004. .Dampak negatif kecanduan pornografi. Diunduh di

(http://aliefqu.wordpress.com/2012/01/16inilahdampaknegatifkecanduanpografi)

Diakses tanggal 10/02/2017 